Article

\title{
Scenarios Analysis of the Energies' Consumption and Carbon Emissions in China Based on a Dynamic CGE Model
}

\author{
Yuanying Chi ${ }^{1}$, Zhengquan Guo ${ }^{2, *}$, Yuhua Zheng ${ }^{3}$ and Xingping Zhang ${ }^{2}$ \\ 1 School of Economics and Management, Beijing University of Technology, Beijing 100022, China; \\ E-Mail: goodcyy@bjut.edu.cn \\ 2 School of Economics and Management, North China Electric Power University, Beinong Road 2, \\ Changping District, Beijing 102206, China; E-Mail: zxp@ncepu.edu.cn \\ 3 School of Management, China University of Mining and Technology (Beijing), Beijing 100083, \\ China; E-Mail: zhengyhts@163.com
}

* Author to whom correspondence should be addressed; E-Mail: zhengquanguo@163.com; Tel.: +86-10-6820-0560.

Received: 19 November 2013; in revised form: 11 January 2014 / Accepted: 15 January 2014 / Published: 23 January 2014

\begin{abstract}
This paper investigates the development trends and variation characteristics of China's economy, energy consumption and carbon emissions from 2007 to 2030, and the impacts on China's economic growth, energy consumption, and carbon emissions under the carbon tax policy scenarios, based on the dynamic computable general equilibrium (CGE) model. The results show that during the simulation period, China's economy will keep a relatively high growth rate, but the growth rate will slow down under the benchmark scenario. The energy consumption intensity and the carbon emissions intensity per unit of Gross Domestic Product (GDP) will continually decrease. The energy consumption structure and industrial structure will gradually optimize. With the economic growth, the total energy consumption will constantly increase, and the carbon dioxide emissions are still large, and the situation of energy-saving and emission-reduction is still serious. The carbon tax is very important for energy-saving and emission-reduction and energy consumption structure optimization, and the effect of the carbon tax on GDP is small. If the carbon tax could be levied and the enterprise income tax could be reduced at the same time, the dual goals of reducing energy consumption and carbon emissions and increasing the GDP growth can be achieved. Improving the technical progress level of clean power while implementing a carbon tax policy is very meaningful to optimize energy consumption structure and reduce the carbon emissions, but it has some offsetting effect to reduce energy consumption.
\end{abstract}


Keywords: dynamic CGE model; energy consumption; carbon emissions; scenario simulation; carbon tax

\section{Introduction}

The computable general equilibrium (CGE) model provides a consistent framework to analyze the economic impacts of energy and environmental policy. It has sound micro-economic foundations and a complete description of the economy with both direct and indirect effects of policy changes. Since the 1980s, the CGE model has been more widely applied and became the mainstream of energy and environmental policy analysis.

Many developed CGE models, researching energy and environmental policy, are static (Akkemik and Oguz [1], Xie and Saltzman [2], Fraser and Waschik [3], Caron [4], Boccanfuso et al. [5]). Interest for forecast and analysis of trends has triggered the flourish of dynamic CGE models. Thus, there are growing numbers of literatur on dynamic CGE models for energy and environmental problems. Vennemo [6] discussed the nature of environmental feedbacks on the Norwegian economy by using the general equilibrium model DREAM (Dynamic Resource/Environment Applied Model). Wendner [7] analyzed environmental tax reforms, which use the revenues from $\mathrm{CO}_{2}$ taxation to partially finance the pension system within the framework of a dynamic computable general equilibrium model (DCGE). By using this DCGE model, Muto et al. [8] simulated the automobile and the related carbon tax needed to accomplish the objective in the transport sector in Japan. Fukiharu [9] used the dynamic general equilibrium approach to examine the effect of the greenhouse effect on the sustainability of human population, as well as the economic policies when the sustainability is in danger. By establishing a single-country (Japan) dynamic computable general equilibrium model with endogenous technological change, Matsumoto [10] evaluated the economic and environmental effects of climate change mitigation in a country scale considering various time horizons in the analysis. O'Ryan et al. [11] developed a dynamic CGE model for Chile and made a quantitative analysis of the socioeconomic and environmental impacts of different trade agreements. This study aimed to compare the consequences of unilateral liberalization and trade agreements from Chile with the performance from European Union (EU) and the United States (USA). Hermeling et al. [12] introduced a new method for stochastic sensitivity analysis for CGE model, based on Gauss Quadrature, and applied it to check the robustness of a large-scale climate policy evaluation before making an impact assessment of EU2020 climate policy.

Meantime, several energy and environment related studies with static CGE models can be found in China. He et al. [13] analyzed the influence of coal price adjustment on the electric power industry, and the influence of electricity price adjustment on the macroeconomy in China, based on a static CGE models. Lin and Jiang [14] applied the price-gap approach to estimate China's energy subsidies and analyzed the economic impacts of energy subsidy reforms in China through a CGE model. The results showed that removing energy subsidies will result in a significant fall in energy demand and emissions, but will impact the macroeconomic variables negatively (See other relevant studies, such as Ren et al. [15], He et al. [16], Lu et al. [17], and Zhang et al. [18]). 
Furthermore, some dynamic CGE models have also been proposed to assess the energy and environment problems in China. Zhang [19,20] analyzed the macroeconomic effects of limiting China's $\mathrm{CO}_{2}$ emissions by using a time-recursive dynamic CGE model of the Chinese economy. The baseline scenario for Chinese economy over the period to 2010 is first developed under a set of assumptions about the exogenous variables. Garbaccio et al. [21] built a recursive dynamic CGE model and evaluated the impacts of carbon tax on the economy of China, whilst considering the coexistence of planned economy and market economy. Liang et al. [22] established a dynamic CGE model to simulate a carbon tax policy in China, and compared the macroeconomic effects of different carbon tax schemes as well as their impacts on the energy- and trade-intensive sectors. By constructing a dynamic recursive general equilibrium model, Lu et al. [23] explored the impact of carbon tax on Chinese economy, as well as the cushion effects of the complementary policies. Recently, based on a multi-sector dynamic CGE model, Tang et al. [24] examined the impacts of the proposed carbon-based border tax adjustments (BTAs) with different tax rates from $\$ 20$ to $\$ 100$ per ton of carbon emissions (tC) imposed by both USA and EU on China's international trade. The simulation results suggested that BTAs would have a negative impact on China's international trade, incurring large losses in both exports and imports.

Dynamic models obviously incorporate the accumulation processes of an economy (in particular, investment), and increase the mid/long term predictive capability of the simulations. Nevertheless, they also increase the complexity of the assessment by adding the trends of the economic variables to the inter-relations in a specific moment of time. In addition, the CGE model is more suitable for the counties and regions in which market economy system is relatively perfect. However, China is in a specific period of transition from a planned to a market economy, and the market equilibrium mechanism is not perfect. In this case, the simulation results of a dynamic CGE model may be quite different from the actual situation. When we plan to set a dynamic CGE model, it requires us to set the relevant parameters of dynamic scene as reasonable as possible to make sure the dynamic simulation results are in accordance with the objective reality of China's economic development.

Therefore, this paper intends to develop a dynamic CGE model to study the development trend and the changing characteristics of economy, energies' consumption and carbon emissions from 2007 to 2030, as well as to analyze the impact of carbon tax policy and clean energy technology progress on economy, energies' consumption, and carbon emission.

This paper is organized as follows: Section 2 introduces the model structures and functions characteristics. Section 3 discusses how to divide the sectors, especially the energies sectors by the RAS (Bi-proportional Scaling Method) method. Section 4 depicts the detailed calculation and handling process of carbon emissions coefficients, and the setting of dynamic benchmark scenario parameters. Section 5 analyzes the variation characteristics of China's gross domestic product, the total energy consumption, energy consumption intensity, carbon emissions, and carbon emissions intensity under the benchmark scenario. Section 6 studies the effects on GDP, energy consumption and carbon emissions under different scenarios of carbon tax policy. Finally, conclusions and suggestions are proposed in Section 7, based on the comprehensive analysis presented in Section 5 and Section 6. 


\section{Theoretical Framework of the CGE Model for China}

\subsection{Production Module}

Production functions for each sector describe the ways in which capital, labor, energy, and intermediate inputs can be used to produce output. Overall, the production process is represented by a seven-layer nested Constant Elasticity of Substitution (CES) function (i.e., constant elasticity of substitute function) as depicted in Figure 1 (where $\sigma_{i}$ is the elasticity of substitute). The top layer of the nest structure comprises the composite primary inputs of labor, capital, and energy, as well as intermediate inputs. Following Burniaux et al. [25] and Huang et al. [26], we assume that the relationship between energy and capital is quasi-complementary, while the substitute elasticity between capital/energy and labor is larger. Therefore, the second layer determines the producer's demand for input of labor and the composite capital and energy. At the third layer, the composite capital and energy is disaggregated into capital and energy. As electricity is mainly generated by consuming fossil fuels, the substitution elasticity between electricity and fossil fuels should be smaller than those within fossil fuels (Wu and Xuan [27]). Therefore, energy is disaggregated into fossil energy and electric power at the fourth layer. At the fifth layer, the electric power is disaggregated into thermal power and clean power, and the fossil energy is disaggregated into coal and composite petroleum energy and gas energy. The composite petroleum energy and gas energy is disaggregated into petroleum energy and gas energy, and the coal energy is disaggregated into coal and coke in the sixth layer. At the bottom layer, the petroleum energy is constituted by crude oil and petroleum, and the gas energy is constituted by natural gas and gas.

Figure 1. Structure of the production function module.

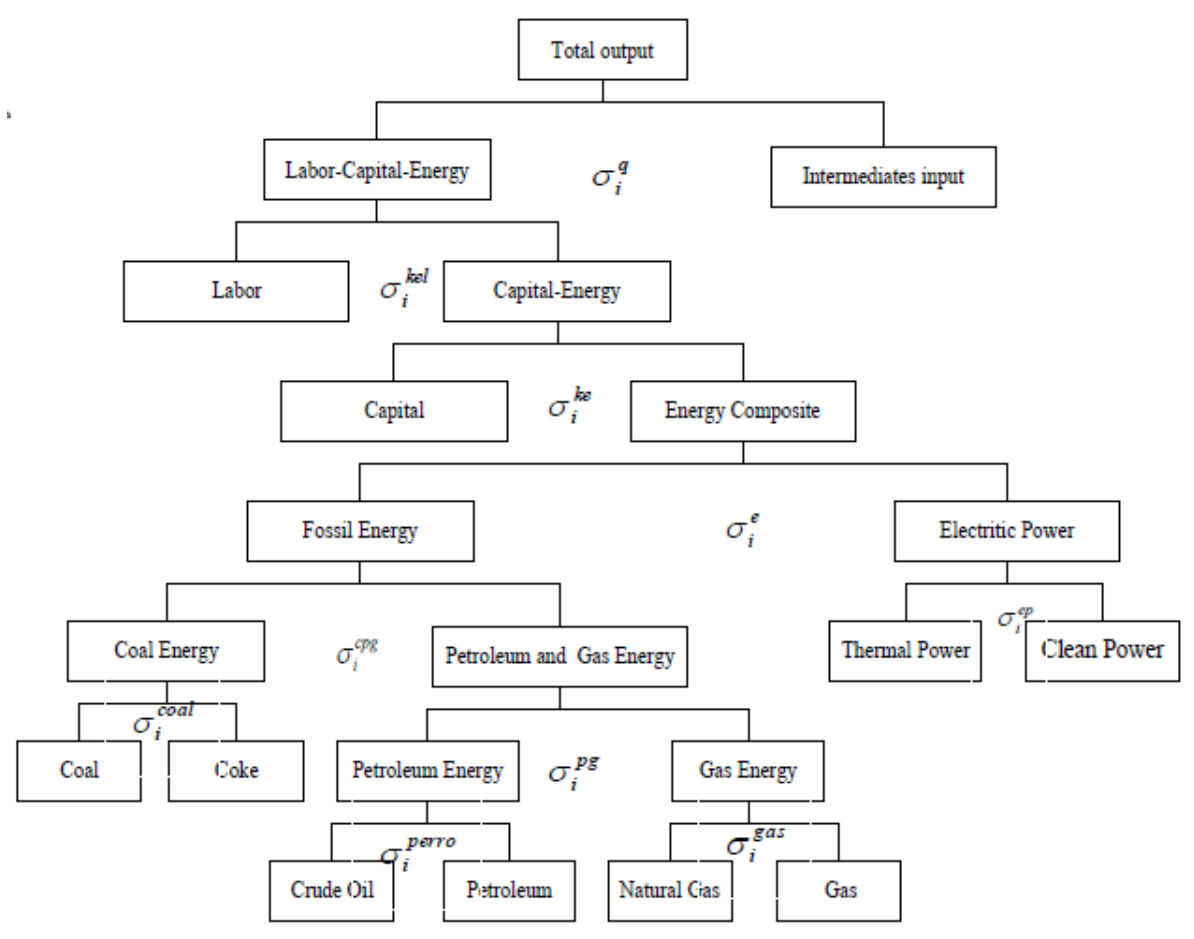

The CES function is applied in the product functions. The optimal combination of input factors is based on the following assumptions: 


$$
\begin{gathered}
\min \sum_{i=1}^{n} P_{i} X_{i} \\
V=A\left[\sum_{i} \beta_{i}\left(\lambda_{i} X_{i}\right)^{\rho}\right]^{\frac{1}{\rho}}
\end{gathered}
$$

where, $X_{i}$ is the input factor $i ; P_{i}$ is the corresponding price; $V$ is the output; $\beta_{i}$ is the share parameter of the factor $i$; $A$ is the overall transformation parameter on all input factors; $\lambda_{i}$ is the transformation parameter on input factor $i ; \rho$ is a coefficient related to the substitution elasticity.

\subsection{International Trade Module}

The substitutability between imported and domestically produced commodities is assumed to be imperfect in this study. Armington assumption, therefore, is applied to solve the problem. The domestically produced commodities and imported commodities are substitutable, they are not completely substitutable. The consumers can choose the best combination of imported and domestic commodities to minimize the costs. The function is shown as follows:

$$
\begin{gathered}
\min \left(P D_{i} \cdot Q D_{i}+P M_{i} \cdot Q M_{i}\right) \\
\text { s.t: } Q Q_{i}=\lambda_{m i}\left[\beta_{d i} Q D_{i}^{\rho_{m i}}+\beta_{m i} Q M_{i}^{\rho_{m i}}\right]^{1 / \rho_{m i}}
\end{gathered}
$$

where $Q D_{i}$ refers to the domestic demand quantity of commodity $i, P D_{i}$ is the price; $Q M_{i}$ refers to the imported quantity of commodity $i, P M_{i}$ refers to the domestic price, $Q Q_{i}$ refers to the total domestic demand quantity, $\beta_{d i}$ and $\beta_{m i}$ refer to the share parameters domestic and import commodity, $\lambda_{m i}$ is the overall transportation parameter between domestic supply and import demand of commodity $i, \rho_{m i}$ is related substitution elasticity of import demand and domestic supply.

We adopt a constant elasticity transformation (CET) function to allocate total domestic output between exports and domestic sales. The function describes the optimal combinations between domestic sales and exports under a certain restriction of production technology. The function is shown as follows:

$$
\begin{gathered}
\max \left(P D_{i} \cdot Q D_{i}+P E_{i} \cdot Q E_{i}\right) \\
\text { s.t: } Q X_{i}=\lambda_{e i}\left[\alpha_{d i} \cdot Q D_{i}^{\rho_{e i}}+\alpha_{e i} \cdot Q E_{i}^{\rho_{e i}}\right]^{1 / \rho_{e i}}
\end{gathered}
$$

where $Q D_{i}$ refers to the domestic sale quantity of commodity $i, P D_{i}$ is the price; $Q E_{i}$ refers to the export quantity of commodity $i, P E_{i}$ refers to the domestic price, $Q X_{i}$ refers to the total domestic output, $\alpha_{d i}$ is the share parameter of domestic sales of commodity $i$, and $\alpha_{e i}$ is the share parameter of export of commodity $i, \lambda_{e i}$ is the overall transportation parameter between domestic sales and export of commodity $i, \rho_{e i}$ is related coefficient of the substitution elasticity.

\subsection{Income and Expenditure}

Household income is mainly from labor income, profit distribution from enterprises, and transfer payment from government and enterprises. Their income is used for consumption and saving. The 
consumption function complies with Stone-Geary utility function assumption. The specific functions are shown as below:

$$
H D_{i} \cdot P Q_{i}=\theta_{i} \cdot P Q_{i}+\beta_{i}\left(Y H-\sum_{i} \theta_{i} \cdot P Q_{i}\right)
$$

where, $Y H$ is the households total disposable income (After-tax income minus household savings); $H D_{i}$ is the households demand quantity of commodity $i ; \theta_{i}$ is the minimum basic demand of commodity $i$; $\beta_{i}$ is the marginal propensity to consumption; $P Q_{i}$ is the demand price of commodity $i$.

The enterprises' income primarily comes from the capital revenue, and their expenditure mainly includes the transfer payment to the inhabitants and the income tax to the government. The left income is for enterprises' savings. For the government, they get the income from indirect taxes, household and enterprises income tax, and tariff, while their expenditure includes transfer payment to the household and enterprises, government consumption, export rebate, and government savings.

\subsection{Social Welfare Module}

For the welfare function, we adopt Hicks Equivalent Variation. Based on commodity prices before the policy implementation, we calculate inhabitants' utility through the demand changes by using the following formula:

$$
E V=E\left(U^{s}, P Q^{b}\right)-E\left(U^{b}, P Q^{b}\right)=\sum_{i} P Q_{i}^{b} \cdot H D_{i}^{s}-\sum_{i} P Q_{i}^{b} \cdot H D_{i}^{b}
$$

where, $E V$ is the equivalent variation of inhabitants' welfare, and $E\left(U^{s}, P Q^{b}\right)$ is the utility after the policy implementation calculated by the payment function based on price before the policy implementation; $E\left(U^{b}, P Q^{b}\right)$ is the utility before the policy implementation; $P Q_{i}^{b}$ is the price of commodity $i$ before the policy implementation; $H D_{i}^{b}$ and $H D_{i}^{s}$ are the inhabitants' consumption before and after the policy implementation, respectively. $E V$ is calculated by the formal formulas. Positive $E V$ means improvement in social welfare and the negative one means deterioration in social welfare after the implementation of the policy.

\subsection{Carbon Tax Module}

In this study, we assume that the carbon emissions mainly come from final consumption of coal, coke, crude oil, petroleum, natural gas, and gas. The carbon tax is calculated though multiplying the demand for various fossil energies by the rate of specific duty on each unit of carbon emissions, and the rate of specific duty on each unit of carbon emissions is endogenously decided under the given reduction target in this study. After converting the rate of specific duty into ad valorem tax rate, the demand price of the fossil energy will be $\left(1+t_{i}\right) \cdot P Q_{i}$. $t_{i}$ is the ad valorem duty rate of fossil energy $i$, and $P Q_{i}$ is the demand price of the fossil energy $i$. In doing so, the carbon tax will directly affect the input and demand cost of fossil energy, and, in turn, affect government revenue. 


\subsection{Model Closure and Market Clearing}

The CGE model in this paper consider three principles of closure: government budget balance, foreign trade balance, and invest-saving balance. When considering the government budget balance, the government consumption is taken as exogenous variable, while government saving is endogenous. For the foreign trade balance, we assume exchange rate is designated endogenously while foreign savings is exogenous variable. The policy impacts on the exchange rate, and then the export and import are involved, even affects the whole economy. For the saving-investment balance, neo-classical closure principles are adopted. The investment is determined by the savings and all the savings in the economy system will be transferred to investment.

In this module, labor market, capital market, and commodity market are cleared by endogenous factor prices. The output of the model must be interpreted as a new equilibrium reached after the economy system has adjusted to the shock. The new equilibrium is the result of a mixture of different impacts, and the net effects of which cannot be derived analytically because the shock inevitably induce adjustments on several intertwined markets. Consequently, numerical simulations, therefore, are necessary in order to obtain the new equilibrium.

\subsection{Dynamic Functions Model}

The dynamic model mainly includes some functions related labor growth, technological progress level (Total Factor Productivity), and capital accumulation and allocation among sectors. In this paper, CET functions are applied to display the allocation of capital among sectors, and this allocation is determined by the sectoral capital revenue rate, the average rate of total capital, and the total supply of social capital. The functions of capital accumulation and allocation are shown as below.

$$
\begin{gathered}
K_{i, t}=\alpha_{i}^{-\rho} \cdot\left(R_{i, t} / A R_{t}\right)^{\rho} \cdot K S_{t} \\
K S_{t}=\operatorname{sum}\left(i, \alpha_{i} \cdot K_{i . t}^{(1+\rho) / \rho}\right)^{\rho /(1+\rho)} \\
K S_{t+1}=K S_{t}-\sum_{i} K_{i, t} \cdot \operatorname{depr}_{i}+T I N V_{t}
\end{gathered}
$$

where, $K_{i, t}$ is the capital demand of sector $i$ in $t$ period, $K S_{t}$ is total supply of social capital in $t$ period, $T I N V_{t}$ is the total investment in $t$ period, $R_{i, t}$ is the capital revenue of sector $i$ in $t$ period, $A R_{t}$ is the social capital average revenue in $t$ period, depr $r_{i}$ is the capital depreciation rate of sector $i$, $\alpha_{i}$ is the share parameter of capital requirement of sector $i, \rho$ is the substitution parameter of capital among sectors.

\section{Model Sectoral Structure}

The CGE model in this paper is created by selecting 23 sectors, required for the carbon tax policy simulation. Most studies, which take the carbon tax policy of China as the research subject, usually integrate the mining and washing of coal sectors and coking sector into one sector, and integrate the petroleum extraction sector and refined oil sector into one sector. Factually, the energy consumption and carbon emissions are significantly different in the production process of those energy sectors. 
For example, the refined oil sector is unique in that it uses crude oil as a "feedstock" to produce refined oil products. The fuel combusted within petroleum refineries typically amounts to 6 to 10 percent of the total fuel input to the refinery, depending on the complexity and vintage of the technology (IPCC, 2006) [28]. Similarly, coal is the important raw material in the coking process. Therefore, if those sectors are integrated into one sector, the feedstock input of crude oil or coal will be taken as the energy input, which may skew the results of policy simulation. According to the energy characteristics of China, this paper further disaggregate energy sectors into eight departments of coal, coke, crude oil, petroleum products, natural gas, gas, thermal power, and clean electricity, it is of great benefit to simulate the carbon tax's impact on China's economic development more accurately. The basic data are compiled from the 2007 Input-Output Table of China [29].

In addition, the sector of extraction of petroleum and the sector of extraction natural gas are integrated into one sector, namely, the sector of extraction of petroleum and natural gas in the Input-Output Tables of China (the 1997 Input-Output Tables of China is an exception) [30]. Disaggregating the sector of extraction of petroleum and natural gas into two sectors (that is, the sector of extraction of petroleum and the sector of extraction natural gas) is require for simulating the carbon tax policy since the input structure of production process and the allocation structure output of extraction of petroleum and extraction of natural gas are significantly different.

This paper takes the sum of the intermediate input rows and columns of Basic Flow Table of 2007 Input-Output Table [29] as the control variables of row and column vectors, respectively. Then, we apply the RAS (Bi-proportional Scaling Method) method, which is an iterative method of bi-proportional adjustment to update the input-output table proposed by Stone in the $1960 \mathrm{~s}$, to compile the data of the sector of extraction petroleum and the sector of extraction natural gas. The data of inhabitants' consumption, government consumption, investment, inventory, import, export, and value-added of Extraction of Petroleum and Natural Gas sectors, are obtained from the 2007 China Input-Output Table [29] and the China Energy Statistical Yearbook [31]. Thus, we adjust 42 and 135 sectors 2007 Input-Output Tables into 23 sectors according to the research need (see Table1).

\section{Setting of Related Date and Parameters}

\subsection{Carbon Emissions Date}

The data of $\mathrm{CO}_{2}$ emissions is calculated by the consumption of fossil energy, as it is unavailable in China. In this paper, the fossil energy fuels include coal, crude oil, natural gas, petroleum products, coking, and gas. The average low-level calorific value of fossil energy fuels comes from the China Energy Statistics Yearbook [30]. The emission coefficients of fossil energy fuels are got from 2006 IPCC Guidelines for National Greenhouse Gas Inventories [27]. The sectoral energy consumption of each type is derived according to the proportion of sector input in total energy consumption. It is worth noting that the crude oil consumption used for petroleum refining is excluded, and the crude coal used for coking and coal gasification, are also excluded. 
Table 1. The sectors definition in the computable general equilibrium (CGE) model and 2007 Input-Output (I/O) table.

\begin{tabular}{|c|c|c|c|}
\hline Code & Sectors classification of $2007 \mathrm{I} / \mathrm{O}$ table & Code & Sectors classification of CGE model \\
\hline 1 & Agriculture, Forestry, Farming of Animals and Fishing & 1 & Agriculture, Forestry, Farming of Animals and Fishing \\
\hline 2 & Mining and Washing of Coal & 2 & Mining and Washing of Coal \\
\hline \multirow{2}{*}{3} & \multirow{2}{*}{ Extraction of Petroleum and Natural Gas } & 3 & Extraction of Petroleum \\
\hline & & 4 & Extraction of Natural Gas \\
\hline 4 & Mining and Processing of Metal Ores & \multirow{2}{*}{5} & \multirow{2}{*}{ Mining and Processing of others Ores } \\
\hline 5 & Mining and Processing of Nonmetal Ores & & \\
\hline 6 & Manufacture and Processing of Foods and Tobacco & 6 & Manufacture and Processing of Foods and Tobacco \\
\hline 7 & Manufacture of Textile & \multirow[b]{2}{*}{7} & \multirow[b]{2}{*}{ Manufacture and Processing of Textile and Related Product } \\
\hline 8 & $\begin{array}{l}\text { Manufacture of Textile Wearing Apparel, Footwear, Caps, Leather, Fur, Feather and Related } \\
\text { Product }\end{array}$ & & \\
\hline 9 & Processing Manufacture of Timber and Furniture & \multirow{2}{*}{8} & Processing Manufacture of Timber, Paper, Printing and \\
\hline 10 & Manufacture of Paper, Printing and Articles For Culture, Education and Sport Activity & & Articles For Culture, Education and Sport Activity \\
\hline \multirow{2}{*}{11} & \multirow{2}{*}{ Processing of Petroleum, Coking, Processing of Nuclear Fuel } & 9 & Processing of Petroleum \\
\hline & & 10 & Coking \\
\hline 12 & Chemical Industry & 11 & Chemical Industry \\
\hline \multirow{2}{*}{13} & \multirow{2}{*}{ Manufacture of Non-metallic Mineral Products } & 12 & Manufacture of Cement, Lime and Gypsum \\
\hline & & 13 & Manufacture of Non-metallic Mineral Products \\
\hline 14 & Smelting and Pressing of Metals & \multirow{2}{*}{14} & \multirow{2}{*}{$\begin{array}{l}\text { Smelting and Pressing and Manufacture of Metals and } \\
\text { Related Product }\end{array}$} \\
\hline 15 & Manufacture of Metal Products & & \\
\hline 16 & Manufacture of General and Special Purpose Machinery & \multirow{3}{*}{15} & \multirow{3}{*}{ Manufacture of Machinery and Equipment } \\
\hline 17 & Manufacture of Transport Equipment & & \\
\hline 18 & Manufacture of Electrical Machinery and Equipment & & \\
\hline 19 & Manufacture of Communication Equipment, Computers and Other Electronic Equipment & \multirow{4}{*}{16} & \multirow{4}{*}{$\begin{array}{l}\text { Manufacture of Communication Equipment,Measuring } \\
\text { Instruments and Other Manufacturing }\end{array}$} \\
\hline 20 & Manufacture of Measuring Instruments and Machinery for Cultural Activity and Office Work & & \\
\hline 21 & Manufacture of Artwork and Other Manufacturing & & \\
\hline 22 & Recycling and Disposal of Waste & & \\
\hline
\end{tabular}


Table 1. Cont.

\begin{tabular}{|c|c|c|c|}
\hline Code & Sectors classification of 2007 I/O table & Code & Sectors classification of CGE model \\
\hline \multirow{2}{*}{23} & \multirow{2}{*}{ Production and Distribution of Electric Power and Heat Power } & 17 & Production and Distribution of thermal Power \\
\hline & & 18 & Production and Distribution of Clean Power \\
\hline 24 & Production and Distribution of Gas & 19 & Production and Distribution of Gas \\
\hline 26 & Construction & 20 & Construction \\
\hline 27 & Transport and Storage & \multirow{2}{*}{21} & \multirow{2}{*}{ Transport ,Storage and Post } \\
\hline 28 & Post & & \\
\hline 29 & Information Transfer, Computer Services and Software & \multirow{6}{*}{22} & \multirow{6}{*}{ Service(1) } \\
\hline 30 & Wholesale and Retail Trade & & \\
\hline 31 & Hotel and Restaurants & & \\
\hline 32 & Finance & & \\
\hline 33 & Real Estate & & \\
\hline 34 & Tenancy and Business Services & & \\
\hline 25 & Production and Distribution of Water & \multirow{9}{*}{23} & \multirow{9}{*}{ Service(2) } \\
\hline 35 & Research and Experimental Development & & \\
\hline 36 & Professional Technique Services & & \\
\hline 37 & Management of Water Conservancy, Environment and Public Establishment & & \\
\hline 38 & Resident Services and Other Services & & \\
\hline 39 & Education & & \\
\hline 40 & Sanitation, Social Security \& Social Welfare & & \\
\hline 41 & Culture, Sports and Entertainment & & \\
\hline 42 & Public Management \& Social Organization & & \\
\hline
\end{tabular}


Table 2. The substitute elasticities of production functions, Armington functions and constant elasticity transformation (CET) functions.

\begin{tabular}{|c|c|c|c|c|c|c|c|c|c|c|c|c|}
\hline \multirow[t]{2}{*}{ Sectors } & \multicolumn{10}{|c|}{ Substitute elasticities of production functions } & \multirow{2}{*}{$\begin{array}{c}\begin{array}{c}\text { Armington } \\
\text { functions }\end{array} \\
\sigma_{m i}\end{array}$} & \multirow{2}{*}{$\begin{array}{c}\begin{array}{c}\text { CET } \\
\text { functions }\end{array} \\
\sigma_{e i}\end{array}$} \\
\hline & $\sigma_{i}^{q}$ & $\sigma_{i}^{k e l}$ & $\sigma_{i}^{k e}$ & $\sigma_{i}^{e}$ & $\sigma_{i}^{c p g}$ & $\sigma_{i}^{p g}$ & $\sigma_{i}^{\text {coal }}$ & $\sigma_{i}^{g a s}$ & $\sigma_{i}^{\text {petro }}$ & $\sigma_{i}^{e p}$ & & \\
\hline Agriculture, Forestry, Farming of Animals and Fishing & 0.3 & 0.8 & 0.6 & 1.2 & 1.2 & 1.3 & 1.25 & 1.6 & 1.25 & 2 & 3 & 4 \\
\hline Mining and Processing of others Ores & 0.3 & 0.8 & 0.6 & 1.2 & 1.2 & 1.3 & 1.25 & 1.6 & 1.25 & 2 & 2.5 & 3.5 \\
\hline Manufacture and Processing of Foods and Tobacco & 0.3 & 0.8 & 0.6 & 1.2 & 1.2 & 1.3 & 1.25 & 1.6 & 1.25 & 2 & 2.5 & 3.5 \\
\hline Manufacture and Processing of Textile and Related Product & 0.3 & 0.8 & 0.6 & 1.2 & 1.2 & 1.3 & 1.25 & 1.6 & 1.25 & 2 & 2.5 & 3.5 \\
\hline $\begin{array}{l}\text { Processing Manufacture of Timber, Paper, Printing and } \\
\text { Articles For Culture, Education and Sport Activity }\end{array}$ & 0.3 & 0.8 & 0.6 & 1.2 & 1.2 & 1.3 & 1.25 & 1.6 & 1.25 & 2 & 2.5 & 3.5 \\
\hline Chemical Industry & 0.3 & 0.8 & 0.6 & 1.2 & 1.2 & 1.3 & 1.25 & 1.6 & 1.25 & 2 & 2.5 & 3.5 \\
\hline Manufacture of Cement, Lime and Gypsum & 0.3 & 0.8 & 0.6 & 1.2 & 1.2 & 1.3 & 1.25 & 1.6 & 1.25 & 2 & 2.5 & 3.5 \\
\hline Manufacture of Non-metallic Mineral Products & 0.3 & 0.8 & 0.6 & 1.2 & 1.2 & 1.3 & 1.25 & 1.6 & 1.25 & 2 & 2.5 & 3.5 \\
\hline $\begin{array}{l}\text { Smelting and Pressing and Manufacture of Metals and } \\
\text { Related Product }\end{array}$ & 0.3 & 0.8 & 0.6 & 1.2 & 1.2 & 1.3 & 1.25 & 1.6 & 1.25 & 2 & 2.5 & 3.5 \\
\hline Manufacture of Machinery and Equipment & 0.3 & 0.8 & 0.6 & 1.2 & 1.2 & 1.3 & 1.25 & 1.6 & 1.25 & 2 & 2.5 & 3.5 \\
\hline $\begin{array}{l}\text { Manufacture of Communication Equipment, Measuring } \\
\text { Instruments and Other Manufacturing }\end{array}$ & 0.3 & 0.8 & 0.6 & 1.2 & 1.2 & 1.3 & 1.25 & 1.6 & 1.25 & 2 & 2.5 & 3.5 \\
\hline Construction & 0.3 & 0.8 & 0.6 & 1.2 & 1.2 & 1.3 & 1.25 & 1.6 & 1.25 & 2 & 2 & 3 \\
\hline Transport ,Storage and Post & 0.3 & 0.8 & 0.6 & 1.2 & 1.2 & 1.3 & 1.25 & 1.6 & 1.25 & 2 & 2 & 3 \\
\hline Service(1) & 0.3 & 0.8 & 0.6 & 1.2 & 1.2 & 1.3 & 1.25 & 1.6 & 1.25 & 2 & 2 & 2.5 \\
\hline Service(2) & 0.3 & 0.8 & 0.6 & 1.2 & 1.2 & 1.3 & 1.25 & 1.6 & 1.25 & 2 & 2 & 2.5 \\
\hline Mining and Washing of Coal & 0.3 & 0.8 & 0.6 & 1.2 & 1.2 & 1.3 & 1.25 & 1.6 & 1.25 & 2 & 2.5 & 3.5 \\
\hline Coking & 0.3 & 0.8 & 0.6 & 1.2 & 1.2 & 1.3 & 1.25 & 1.6 & 1.25 & 2 & 2.5 & 3.5 \\
\hline Extraction of Petroleum & 0.3 & 0.8 & 0.6 & 1.2 & 1.2 & 1.3 & 1.25 & 1.6 & 1.25 & 2 & 2.5 & 3.5 \\
\hline Processing of Petroleum & 0.3 & 0.8 & 0.6 & 1.2 & 1.2 & 1.3 & 1.25 & 1.6 & 1.25 & 2 & 2.5 & 3.5 \\
\hline Extraction of Natural Gas & 0.3 & 0.8 & 0.6 & 1.2 & 1.2 & 1.3 & 1.25 & 1.6 & 1.25 & 2 & 2.5 & 3.5 \\
\hline Production and Distribution of Gas & 0.3 & 0.8 & 0.6 & 1.2 & 1.2 & 1.3 & 1.25 & 1.6 & 1.25 & 2 & 2.5 & 3.5 \\
\hline Production and Distribution of thermal Power & 0.3 & 0.8 & 0.6 & 1.2 & 1.2 & 1.3 & 1.25 & 1.6 & 1.25 & 2 & 2 & 3 \\
\hline Production and Distribution of Clean Power & 0.3 & 0.8 & 0.6 & 1.2 & 1.2 & 1.3 & 1.25 & 1.6 & 1.25 & 2 & 2 & 3 \\
\hline
\end{tabular}




\subsection{Benchmark Scenario Parameters}

The exogenous parameters in this model include the substitute elasticities of productive functions, Armington functions and CET functions, the growth rate of labor force, total factor productivity (TFP), structure coefficients of intermediate input and output, inhabitants' savings rate, the trade surplus. The setting of the substitute elasticity of productive functions, Armington functions and CET functions refers to related research (He et al. [32], Wang [33], Xuan [34], Tan [35]), and with our own adjustment (see Table 2). The growth rates of labor force are presumed according to China's actual employment situation and the some scholars' predictions [36-38] (see Table 3).

Table 3. The estimate of labor force growth rates (\%).

\begin{tabular}{cccccc}
\hline Year & 2008-2010 & $\mathbf{2 0 1 1 - 2 0 1 5}$ & $\mathbf{2 0 1 6 - 2 0 2 0}$ & $\mathbf{2 0 2 1 - 2 0 2 5}$ & $\mathbf{2 0 2 6 - 2 0 3 0}$ \\
Categories & -0.01 & -0.01 & -0.01 & -0.01 & 0 \\
Primary Industry & 0.01 & 0.01 & 0.01 & 0.01 & 0 \\
Secondary industry & 0.03 & 0.03 & 0.03 & 0.03 & 0.03 \\
Tertiary Industry & 0.03 &
\end{tabular}

It is assumed TFP is the same in most sectors, as shown in Table 4, during simulation period, except for Extraction of Petroleum and Extraction of Natural Gas. China's energy resources and sustainable supply capacity of conventional fossil energies are insufficient. Annual output of petroleum can only be maintained at around 200 million tons. New increased production of conventional natural gas can only meet about $30 \%$ of the new demand. The proved reserves and the output of unconventional gas resources of coal bed methane and shale gas will have relatively high growth rates, which will be an important growth pole of natural gas the supply. Therefore, it is assumed that the TFP growth rate of Extraction of Petroleum is 0 during the simulation period, because the extraction costs will gradually increase due to the limitation of reserves and extracted geological conditions. The TFP growth rate of natural gas is slightly higher than the national average due to the gradual exploitation of unconventional natural gas.

Table 4. The total factor productivity (TFP) during the Simulation period (\%).

\begin{tabular}{lcccccc}
\hline Year & 2008-2010 & 2011-2015 & 2016-2020 & $\mathbf{2 0 2 1 - 2 0 2 5}$ & 2026-2030 \\
\hline TFP growth rate & $3-2.5$ & 2.0 & 2.0 & 2.0 & 2.0 \\
\hline
\end{tabular}

According to China Input-Output Table published, and with reference to the variation characteristics of intermediate input rate of the United States and Japan Input-Output Table, a certain setting to the intermediate inputs rate is made during the benchmark scenario. With the economic development and social progress it is projected that the inhabitants' savings rate will gradually decline. Under the benchmark scenario, the inhabitants' savings will drop from the current 38\% to a level of around $20 \%$. It is also assumed the trade surplus will gradually decrease, as well and achieve trade balance in the year of 2030 . 
Table 5. The analysis of GDP, energy consumption and carbon emissions (benchmark scenario).

\begin{tabular}{|c|c|c|c|c|c|c|}
\hline \multirow{2}{*}{ Year } & \multirow{2}{*}{$\begin{array}{c}\text { GDP } \\
10^{9} \text { Yuan }\end{array}$} & \multirow{2}{*}{$\begin{array}{c}\text { GDP } \\
\text { growth rate }\end{array}$} & \multirow{2}{*}{$\begin{array}{c}\text { Total energy consumption } \\
10^{4} \text { tons standard coal }\end{array}$} & \multirow{2}{*}{$\begin{array}{c}\text { Energy consumption intensity } \\
\text { ton standard coal } / 10^{4} \text { Yuan }\end{array}$} & \multirow{2}{*}{$\begin{array}{c}\text { Total carbon emissions } \\
10^{4} \text { tons }\end{array}$} & \multirow{2}{*}{$\begin{array}{c}\text { Carbon emissions intensity } \\
\text { tons } / 10^{4} \text { Yuan } \\
\end{array}$} \\
\hline & & & & & & \\
\hline 2007 & $266,043.81$ & & $265,583.00$ & 0.9983 & $615,148.72$ & 2.3122 \\
\hline 2008 & $291,784.56$ & $9.68 \%$ & $284,167.41$ & 0.9739 & $660,032.34$ & 2.2621 \\
\hline 2009 & $319,534.13$ & $9.51 \%$ & $304,393.76$ & 0.9526 & $708,488.25$ & 2.2173 \\
\hline 2010 & $348,977.02$ & $9.21 \%$ & $326,039.21$ & 0.9343 & $759,919.82$ & 2.1776 \\
\hline 2011 & $378,873.57$ & $8.57 \%$ & $347,990.11$ & 0.9185 & $811,920.90$ & 2.1430 \\
\hline 2012 & $410,927.86$ & $8.46 \%$ & $370,806.39$ & 0.9024 & $865,955.37$ & 2.1073 \\
\hline 2013 & $445,106.89$ & $8.32 \%$ & $394,372.07$ & 0.8860 & $921,761.50$ & 2.0709 \\
\hline 2014 & $481,380.72$ & $8.15 \%$ & $418,581.23$ & 0.8695 & $979,101.12$ & 2.0339 \\
\hline 2015 & $519,724.50$ & $7.97 \%$ & $443,339.81$ & 0.8530 & $1,037,763.70$ & 1.9968 \\
\hline 2016 & $560,095.26$ & $7.77 \%$ & $468,451.98$ & 0.8364 & $1,097,386.89$ & 1.9593 \\
\hline 2017 & $602,500.84$ & $7.57 \%$ & $493,936.92$ & 0.8198 & $1,157,956.90$ & 1.9219 \\
\hline 2018 & $646,938.82$ & $7.38 \%$ & $519,737.19$ & 0.8034 & $1,219,349.89$ & 1.8848 \\
\hline 2019 & $693,416.10$ & $7.18 \%$ & $545,808.60$ & 0.7871 & $1,281,472.32$ & 1.8481 \\
\hline 2020 & $741,949.05$ & $7.00 \%$ & $572,119.50$ & 0.7711 & $1,344,259.24$ & 1.8118 \\
\hline 2021 & $790,685.52$ & $6.57 \%$ & $596,432.42$ & 0.7543 & $1,402,048.06$ & 1.7732 \\
\hline 2022 & $841,039.57$ & $6.37 \%$ & $620,529.75$ & 0.7378 & $1,459,396.16$ & 1.7352 \\
\hline 2023 & $893,030.58$ & $6.18 \%$ & $644,412.30$ & 0.7216 & $1,516,308.85$ & 1.6979 \\
\hline 2024 & $946,688.13$ & $6.01 \%$ & $668,090.31$ & 0.7057 & $1,572,812.60$ & 1.6614 \\
\hline 2025 & $1,002,051.62$ & $5.85 \%$ & $691,582.07$ & 0.6902 & $1,628,951.83$ & 1.6256 \\
\hline 2026 & $1,058,592.06$ & $5.64 \%$ & $714,867.83$ & 0.6753 & $1,684,753.17$ & 1.5915 \\
\hline 2027 & $1,116,874.21$ & $5.51 \%$ & $738,002.17$ & 0.6608 & $1,740,281.05$ & 1.5582 \\
\hline 2028 & $1,176,958.19$ & $5.38 \%$ & $761,019.99$ & 0.6466 & $1,795,616.71$ & 1.5256 \\
\hline 2029 & $1,238,913.42$ & $5.26 \%$ & $783,961.01$ & 0.6328 & $1,850,851.71$ & 1.4939 \\
\hline 2030 & $1,302,818.49$ & $5.16 \%$ & $806,869.01$ & 0.6193 & $1,906,086.38$ & 1.4630 \\
\hline
\end{tabular}




\section{Simulation Analyses of the Dynamic Benchmark Scenario}

According to the parameter setting of benchmark scenario and the model simulation analyses, Table 5 presents the variation characteristics of China's GDP, the total energy consumption, energy consumption intensity, carbon emissions, and carbon emissions intensity under the benchmark scenario. It is shown that, from 2007 to 2030, China's GDP will still grow rapidly. The GDP will increase from 26,604.381 billion Yuan in 2006 to $130,281.849$ billion Yuan in 2030, but its growth rate will slow down. The economic growth rate mainly depends on the labor input, capital accumulation, and TFP. The main reason why the economic growth rate gradually decreases is that the capital accumulation is increasing compared with the labor input, leading to the gradual decrease of the marginal product of capital and the decrease of the GDP growth rate.

At the same time, the energy consumption and carbon emissions increase significantly during the simulation period. The energy consumption will increase by 3.04 times from 265.58 million tons standard coal in 2007 to 806.87 in 2030 . The carbon emissions of fossil energy will rise by 3.01 times from 615.15 billion tons in 2007 to 1906.07 billion tons in 2030. However, the energy consumption intensity per unit of GDP, and carbon emissions intensity per unit of GDP gradually decline. The energy consumption intensity per unit of GDP will reduce form 0.9983 tons standard coal/ $10^{4}$ Yuan in 2007 to 0.61933 tons standard coal $/ 10^{4}$ Yuan in 2030. The carbon emissions intensity per unit of GDP will reduce form 2.3122 tons $/ 10^{4}$ Yuan in 2007 to 1.4631 tons $/ 10^{4}$ Yuan in 2030. In a word, although the energy consumption intensity and carbon emissions intensity decrease significantly, the total energy consumption continues growing. Large amounts of carbon emissions, caused by energy consumption, will bring great environmental pressure.

Table 6 reveals China's total primary energy consumption and its composition under the benchmark scenario. China's primary energy consumption continues to increase with the increase of GDP. But the structure of primary energy consumption has been improved apparently. The proportion of coal in China's total primary energy consumption will reduce from $69.50 \%$ in 2007 to $58.17 \%$ in 2030 . The proportion of natural gas, hydropower, nuclear power, and wind power in China's total primary energy consumption will go up significantly. The proportion of natural gas will increase from $3.50 \%$ in 2007 to $7.03 \%$ in 2030 , and the proportion of hydropower, nuclear power, and wind power will increase from $7.30 \%$ in 2007 to $12.69 \%$ in 2030 . The proportion of petroleum in China's total primary energy consumption will rise slightly.

Under the benchmark scenario, the energy consumption intensity and carbon emission intensity decrease gradually. The optimization and upgrading of industrial structure in China is a major reason for gradual decline of energy consumption intensity. Table 7 shows the development characteristics of China's GDP and its composition under the benchmark scenario. From the simulation, we can see the proportion of China's first industry in GDP will obviously reduce with a distinct increase for the proportion of China's third industry from $38.88 \%$ in 2007 to $50.57 \%$ in 2030 . For the proportion of the second industry with high-energy-consumption in GDP, it gradually drops from 50.35\% in 2007 to $44.81 \%$ in 2030. Therefore, the energy consumption intensity per unit of GDP in China will gradually reduce due to the optimization of the industrial structure. Apart from this, the other reason is, during the simulation period, with the reduction of the output proportion of the second industry, the proportion of the output of capital goods sectors in the total output of the second industry will be unchanged or slightly higher 
because of the increased demand. As the energy industry being important sectors of the second industry, the proportion of its output in the total output will reduce gradually. Due to the relatively reduced supply, the cost of the energy input will, relatively, go up in the production process. Therefore, enterprises will increasingly improve the efficiency of energy inputs.

Table 6. China's total primary energy consumption and its composition (Benchmark scenario).

\begin{tabular}{lccccc}
\hline \multirow{2}{*}{ Year } & Total energy consumption & \multicolumn{3}{c}{ The proportion in total primary energies' consumption } \\
\cline { 2 - 6 } & $\mathbf{1 0}$ tons standard coal & Coal & Petroleum & Natural gas & $\begin{array}{c}\text { Hydro power, nuclear } \\
\text { power, and wind power }\end{array}$ \\
\hline 2007 & $265,583.00$ & $69.50 \%$ & $19.70 \%$ & $3.50 \%$ & $7.30 \%$ \\
\hline 2008 & $284,167.41$ & $69.18 \%$ & $19.75 \%$ & $3.57 \%$ & $7.50 \%$ \\
\hline 2009 & $304,393.76$ & $68.82 \%$ & $19.81 \%$ & $3.65 \%$ & $7.71 \%$ \\
\hline 2010 & $326,039.21$ & $68.44 \%$ & $19.88 \%$ & $3.74 \%$ & $7.95 \%$ \\
\hline 2011 & $347,990.11$ & $68.01 \%$ & $19.99 \%$ & $3.84 \%$ & $8.16 \%$ \\
\hline 2012 & $370,806.39$ & $67.56 \%$ & $20.10 \%$ & $3.96 \%$ & $8.38 \%$ \\
\hline 2013 & $394,372.07$ & $67.09 \%$ & $20.22 \%$ & $4.08 \%$ & $8.61 \%$ \\
\hline 2015 & $418,581.23$ & $66.61 \%$ & $20.34 \%$ & $4.22 \%$ & $8.84 \%$ \\
\hline 2016 & $443,339.81$ & $66.11 \%$ & $20.45 \%$ & $4.37 \%$ & $9.07 \%$ \\
\hline 2017 & $468,451.98$ & $65.63 \%$ & $20.58 \%$ & $4.49 \%$ & $9.30 \%$ \\
\hline 2018 & $493,936.92$ & $65.14 \%$ & $20.70 \%$ & $4.62 \%$ & $9.54 \%$ \\
\hline 2019 & $519,737.19$ & $64.65 \%$ & $20.82 \%$ & $4.76 \%$ & $9.77 \%$ \\
\hline 2020 & $545,808.60$ & $64.16 \%$ & $20.93 \%$ & $4.91 \%$ & $10.01 \%$ \\
\hline 2021 & $572,119.50$ & $63.66 \%$ & $21.04 \%$ & $5.06 \%$ & $10.24 \%$ \\
\hline 2023 & $596,432.42$ & $63.11 \%$ & $21.17 \%$ & $5.23 \%$ & $10.50 \%$ \\
\hline 2024 & $620,529.75$ & $62.56 \%$ & $21.30 \%$ & $5.40 \%$ & $10.75 \%$ \\
\hline 2025 & $644,412.30$ & $62.01 \%$ & $21.42 \%$ & $5.58 \%$ & $11.00 \%$ \\
\hline 2026 & $668,090.31$ & $61.45 \%$ & $21.54 \%$ & $5.77 \%$ & $11.24 \%$ \\
\hline 2027 & $691,582.07$ & $60.90 \%$ & $21.65 \%$ & $5.96 \%$ & $11.49 \%$ \\
\hline 2028 & $714,867.83$ & $60.36 \%$ & $21.75 \%$ & $6.16 \%$ & $11.73 \%$ \\
\hline 2030 & $738,002.17$ & $59.81 \%$ & $21.85 \%$ & $6.37 \%$ & $11.98 \%$ \\
\hline & $761,019.99$ & $59.26 \%$ & $21.94 \%$ & $6.58 \%$ & $12.22 \%$ \\
\hline $783,961.01$ & $58.72 \%$ & $22.03 \%$ & $6.80 \%$ & $12.69 \%$ \\
\hline
\end{tabular}

During the simulation period, the carbon emissions intensity decreases gradually. The main reasons are listed as follows: (1) the energy efficiency gradually increases; (2) the structure of primary energy consumption is gradually optimized with the decline of the proportion of coal in China's total primary energy consumption and the increase of the proportion of clean power; and (3) the industrial structure is optimized and upgraded.

Generally speaking, under the benchmark scenario, China will keep a relatively high growth rate in economy, but the growth rate will slow down. The energy consumption structure and industrial structure will be optimized step by step. Through the energy consumption intensity per unit of GDP and carbon emissions intensity per unit of GDP decrease, total energy consumption will increase, and total $\mathrm{CO}_{2}$ emissions caused by a large amount of energy consumption will pose huge pressure on the environment in the future. The situation of energy-saving and emission-reduction will be grim. 
Table 7. Analysis of GDP and its composition (Benchmark scenario).

\begin{tabular}{ccccc}
\hline \multirow{2}{*}{ Year } & GDP & \multicolumn{3}{c}{ The proportion of three industries } \\
\cline { 2 - 5 } & $\mathbf{1 0}$ Yuan & The primary industry & The secondary industry & The tertiary industry \\
\hline 2007 & $266,043.81$ & $10.77 \%$ & $50.35 \%$ & $38.88 \%$ \\
\hline 2008 & $291,784.56$ & $10.36 \%$ & $50.30 \%$ & $39.34 \%$ \\
\hline 2009 & $319,534.13$ & $9.95 \%$ & $50.23 \%$ & $39.82 \%$ \\
\hline 2010 & $348,977.02$ & $9.56 \%$ & $50.15 \%$ & $40.30 \%$ \\
\hline 2011 & $378,873.57$ & $9.11 \%$ & $50.08 \%$ & $40.81 \%$ \\
\hline 2012 & $410,927.86$ & $8.69 \%$ & $49.98 \%$ & $41.33 \%$ \\
\hline 2013 & $445,106.89$ & $8.30 \%$ & $49.87 \%$ & $41.83 \%$ \\
\hline 2014 & $481,380.72$ & $7.93 \%$ & $49.74 \%$ & $42.33 \%$ \\
\hline 2015 & $519,724.50$ & $7.59 \%$ & $49.59 \%$ & $42.82 \%$ \\
\hline 2016 & $560,095.26$ & $7.28 \%$ & $49.42 \%$ & $43.30 \%$ \\
\hline 2017 & $602,500.84$ & $6.99 \%$ & $49.24 \%$ & $43.77 \%$ \\
\hline 2018 & $646,938.82$ & $6.72 \%$ & $49.04 \%$ & $44.24 \%$ \\
\hline 2019 & $693,416.10$ & $6.48 \%$ & $48.83 \%$ & $44.69 \%$ \\
\hline 2020 & $741,949.05$ & $6.25 \%$ & $48.61 \%$ & $45.14 \%$ \\
\hline 2021 & $790,685.52$ & $6.05 \%$ & $48.26 \%$ & $45.69 \%$ \\
\hline 2022 & $841,039.57$ & $5.87 \%$ & $47.90 \%$ & $46.23 \%$ \\
\hline 2023 & $893,030.58$ & $5.71 \%$ & $47.52 \%$ & $46.77 \%$ \\
\hline 2024 & $946,688.13$ & $5.55 \%$ & $47.14 \%$ & $47.31 \%$ \\
\hline 2025 & $1,002,051.62$ & $5.41 \%$ & $46.74 \%$ & $47.85 \%$ \\
\hline 2026 & $1,058,592.06$ & $5.23 \%$ & $46.37 \%$ & $48.40 \%$ \\
\hline 2027 & $1,116,874.21$ & $5.07 \%$ & $45.99 \%$ & $48.94 \%$ \\
\hline 2028 & $1,176,958.19$ & $4.91 \%$ & $45.60 \%$ & $49.49 \%$ \\
\hline 2029 & $1,238,913.42$ & $4.76 \%$ & $45.21 \%$ & $50.03 \%$ \\
\hline 2030 & $1,302,818.49$ & $4.63 \%$ & $44.81 \%$ & \\
\hline & & & & \\
\hline
\end{tabular}

\section{Simulation Analysis of Carbon Tax Policy}

According to simulation analysis under the benchmark scenario, with China's economic growth, energy consumption and carbon emissions will continue to increase and the situation of energy-saving and emission-reduction will be very serious in future. The carbon tax policy can be an effective tool to address climate changes, energy-saving, and emission-reduction. Therefore, we will analyze how the carbon tax and technical progress impact the energy consumption and carbon emissions in China. Three assumptions are adopted in the following scenarios.

Carbon tax scenario I: It is assumed that the carbon tax is implemented as of 2016. The annual carbon dioxide emissions will be reduced by $10 \%$ than under the benchmark scenario.

Carbon tax scenario II: It is assumed that the carbon tax is implemented as of 2016. The annual carbon dioxide emissions will be reduced by $10 \%$ than under the benchmark scenario. The enterprise income tax will be reduced accordingly, and the annual government revenue during the simulation period will be consistent with that in the benchmark scenario. 
Table 8. The analysis of GDP, energy consumption and carbon emission intensity (Scenario I).

\begin{tabular}{|c|c|c|c|c|c|c|c|c|}
\hline \multirow{2}{*}{ Year } & \multirow{2}{*}{$\begin{array}{c}\text { GDP } \\
10^{9} \text { Yuan }\end{array}$} & \multirow{2}{*}{$\begin{array}{c}\text { Percentage } \\
\text { change } \\
\text { of GDP }\end{array}$} & \multirow{2}{*}{$\begin{array}{c}\begin{array}{c}\text { Total energy } \\
\text { consumption }\end{array} \\
10^{4} \text { tons } \\
\text { standard coal } \\
\end{array}$} & \multirow{2}{*}{$\begin{array}{c}\text { Percentage } \\
\text { of change } \\
\text { total energy } \\
\text { consumption } \\
\end{array}$} & \multirow{2}{*}{$\begin{array}{c}\text { Energy consumption } \\
\text { intensity } \\
\text { ton standard } \\
\text { coal } / \mathbf{1 0}^{4} \text { Yuan } \\
\end{array}$} & \multirow{2}{*}{$\begin{array}{l}\text { Percentage change of } \\
\text { energy consumption } \\
\text { intensity }\end{array}$} & \multirow{2}{*}{$\begin{array}{c}\begin{array}{c}\text { Carbon emissions } \\
\text { intensity }\end{array} \\
\text { tons } / 10^{4} \text { Yuan }\end{array}$} & \multirow{2}{*}{$\begin{array}{c}\text { Percentage change of } \\
\text { carbon emissions } \\
\text { intensity }\end{array}$} \\
\hline & & & & & & & & \\
\hline 2016 & $559,532.02$ & $-0.1006 \%$ & $428,062.91$ & $-8.62 \%$ & 0.7650 & $-8.53 \%$ & 1.7814 & $-9.08 \%$ \\
\hline 2017 & $601,896.78$ & $-0.1003 \%$ & $451,532.57$ & $-8.58 \%$ & 0.7502 & $-8.49 \%$ & 1.7502 & $-8.93 \%$ \\
\hline 2018 & $646,293.14$ & $-0.0998 \%$ & $475,313.45$ & $-8.55 \%$ & 0.7354 & $-8.46 \%$ & 1.7192 & $-8.79 \%$ \\
\hline 2019 & $692,726.81$ & $-0.0994 \%$ & $499,365.23$ & $-8.51 \%$ & 0.7209 & $-8.41 \%$ & 1.6884 & $-8.64 \%$ \\
\hline 2020 & $741,212.83$ & $-0.0992 \%$ & $523,659.03$ & $-8.47 \%$ & 0.7065 & $-8.38 \%$ & 1.6580 & $-8.49 \%$ \\
\hline 2021 & $789,908.34$ & $-0.0983 \%$ & $546,172.81$ & $-8.43 \%$ & 0.6914 & $-8.33 \%$ & 1.6252 & $-8.34 \%$ \\
\hline 2022 & $840,217.98$ & $-0.0977 \%$ & $568,512.56$ & $-8.38 \%$ & 0.6766 & $-8.29 \%$ & 1.5929 & $-8.20 \%$ \\
\hline 2023 & $892,159.56$ & $-0.0975 \%$ & $590,678.54$ & $-8.34 \%$ & 0.6621 & $-8.25 \%$ & 1.5610 & $-8.06 \%$ \\
\hline 2024 & $945,761.04$ & $-0.0979 \%$ & $612,679.65$ & $-8.29 \%$ & 0.6478 & $-8.20 \%$ & 1.5296 & $-7.93 \%$ \\
\hline 2025 & $1,001,060.16$ & $-0.0989 \%$ & $634,532.26$ & $-8.25 \%$ & 0.6339 & $-8.16 \%$ & 1.4988 & $-7.80 \%$ \\
\hline 2026 & $1,057,523.87$ & $-0.1009 \%$ & $656,218.28$ & $-8.20 \%$ & 0.6205 & $-8.11 \%$ & 1.4699 & $-7.64 \%$ \\
\hline 2027 & $1,115,717.24$ & $-0.1036 \%$ & $677,786.79$ & $-8.16 \%$ & 0.6075 & $-8.07 \%$ & 1.4417 & $-7.48 \%$ \\
\hline 2028 & $1,175,698.62$ & $-0.1070 \%$ & $699,269.55$ & $-8.11 \%$ & 0.5948 & $-8.02 \%$ & 1.4140 & $-7.31 \%$ \\
\hline 2029 & $1,237,535.64$ & $-0.1112 \%$ & $720,702.76$ & $-8.07 \%$ & 0.5824 & $-7.97 \%$ & 1.3870 & $-7.16 \%$ \\
\hline 2030 & $1,301,305.14$ & $-0.1162 \%$ & $742,126.52$ & $-8.02 \%$ & 0.5703 & $-7.91 \%$ & 1.3605 & $-7.00 \%$ \\
\hline
\end{tabular}


Carbon tax scenario III: It is assumed that the carbon tax policy is implemented as of 2016. The annual carbon dioxide emissions will be reduced by $10 \%$ than under the benchmark scenario. Technology of clean power is promoted, and total factor productivity will be one time higher than that under the benchmark scenario.

Thus, we analyze the influence of different policy scenarios on GDP, energy consumption, energy consumption structure, carbon emissions, and carbon emissions intensity.

Carbon tax scenario I: Due to the levy on carbon tax, GDP drops slightly from that in the benchmark scenario (see Table 8). Specifically, due to the carbon tax, the input cost of fossil energy fuels increases, and the energy input of sectors reduces, leading to the reduction of the output and GDP to a certain extent. In another aspect, GDP will be equal to the final demand, because the increased prices of fossil energy fuels will cause the increase of the demand prices of the goods, resulting in the decrease of final demand. Due to the carbon tax, the cost of fossil energy fuels will rise. As a consequence, the total energy consumption decreases significantly by $8 \%$ of that under the benchmark scenario. For the total primary energy consumption and its composition (see Table 9), coal carbon emission coefficient is big, thus, the carbon tax has an obvious influence on coal consumption, decreasing the proportion of coal in the total energy consumption significantly compared with under the benchmark scenario. However, the proportions of oil and natural gas increase slightly, and the proportion of clean power increases significantly, thus, the primary energy consumption structure is optimized to some extent. Accordingly, energy consumption intensity decreases about $8 \%$ than that under the benchmark scenario. Due to the decline of the total energy consumption and the coal proportion in primary energy structure, carbon emissions intensity reduces about $7 \%-9 \%$ above that in the benchmark scenario.

Table 9. The total primary energy consumption and its composition (scenario I).

\begin{tabular}{cccccc}
\hline Year & $\begin{array}{c}\text { Total energy } \\
\text { consumption }\end{array}$ & \multicolumn{2}{c}{ The proportion in total primary energies' consumption } \\
\cline { 2 - 6 } & $\mathbf{1 0}^{\mathbf{4}}$ tons standard coal & Coal & Petroleum & Natural gas & $\begin{array}{c}\text { Hydro power, nuclear } \\
\text { power, and wind power }\end{array}$ \\
\hline 2016 & $428,062.91$ & $62.52 \%$ & $22.34 \%$ & $4.76 \%$ & $10.38 \%$ \\
\hline 2017 & $451,532.57$ & $62.01 \%$ & $22.46 \%$ & $4.89 \%$ & $10.64 \%$ \\
\hline 2018 & $475,313.45$ & $61.51 \%$ & $22.57 \%$ & $5.03 \%$ & $10.89 \%$ \\
\hline 2019 & $499,365.23$ & $61.00 \%$ & $22.68 \%$ & $5.18 \%$ & $11.15 \%$ \\
\hline 2020 & $523,659.03$ & $60.50 \%$ & $22.78 \%$ & $5.33 \%$ & $11.40 \%$ \\
\hline 2021 & $546,172.81$ & $59.93 \%$ & $22.91 \%$ & $5.49 \%$ & $11.67 \%$ \\
\hline 2022 & $568,512.56$ & $59.37 \%$ & $23.03 \%$ & $5.66 \%$ & $11.94 \%$ \\
\hline 2023 & $590,678.54$ & $58.81 \%$ & $23.14 \%$ & $5.84 \%$ & $12.21 \%$ \\
\hline 2024 & $612,679.65$ & $58.25 \%$ & $23.25 \%$ & $6.02 \%$ & $12.48 \%$ \\
\hline 2025 & $634,532.26$ & $57.69 \%$ & $23.36 \%$ & $6.21 \%$ & $12.74 \%$ \\
\hline 2026 & $656,218.28$ & $57.14 \%$ & $23.45 \%$ & $6.41 \%$ & $13.00 \%$ \\
\hline 2027 & $677,786.79$ & $56.59 \%$ & $23.54 \%$ & $6.61 \%$ & $13.26 \%$ \\
\hline 2028 & $699,269.55$ & $56.05 \%$ & $23.62 \%$ & $6.82 \%$ & $13.52 \%$ \\
\hline 2029 & $720,702.76$ & $55.50 \%$ & $23.70 \%$ & $7.03 \%$ & $13.77 \%$ \\
\hline 2030 & $742,126.52$ & $54.95 \%$ & $23.78 \%$ & $7.25 \%$ & $14.02 \%$ \\
\hline
\end{tabular}


Table 10. The analysis of GDP, energy consumption and carbon emission intensity (Scenario II).

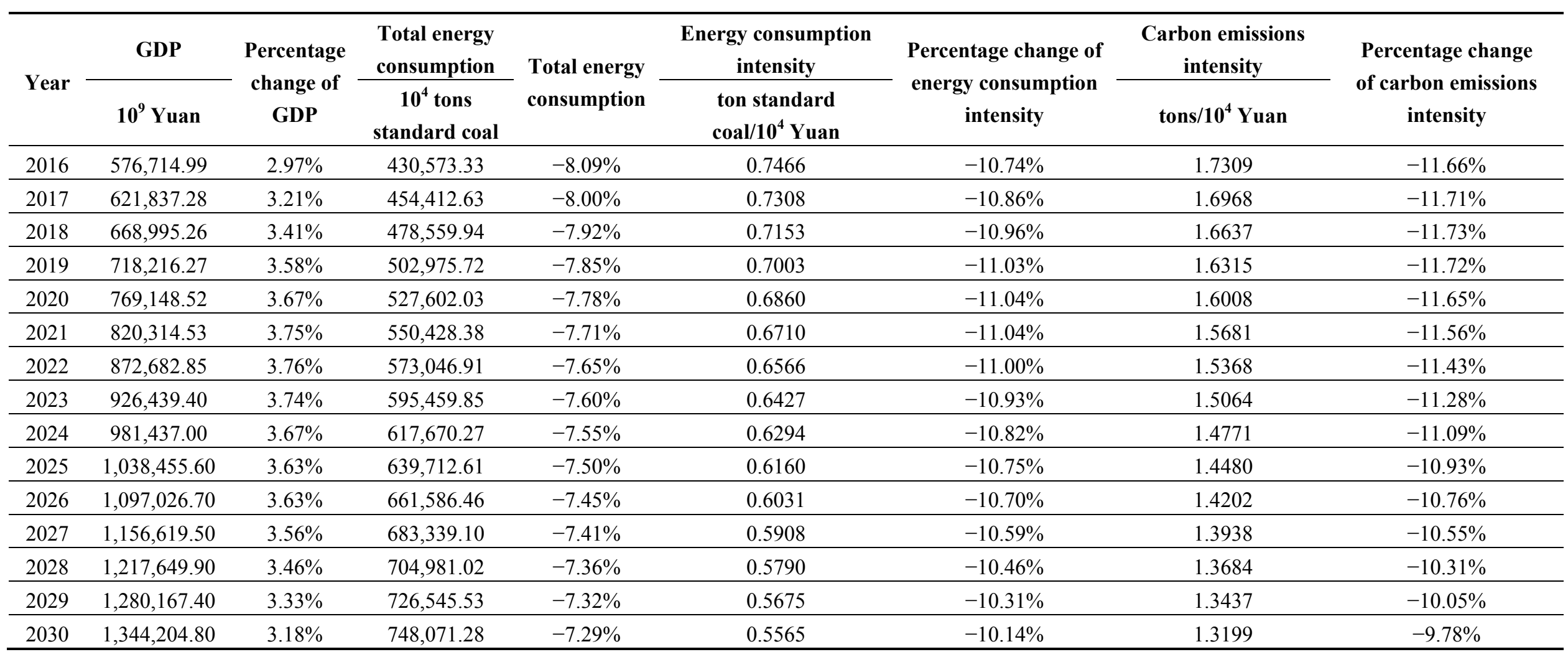


Carbon tax scenario II: Compared with the benchmark scenario, GDP rises to a certain degree (see Table 10). The reason is that although the carbon tax results in the improvement of production cost and the slight decrease of GDP, the carbon tax also leads to the reduction of enterprise income tax, which is then directly used for investment, directly boosting economy growth. Therefore, GDP even rises more than $3 \%$ under the benchmark scenario rather than decrease. At the same time, the total energy consumption decreases by $7 \%-8 \%$ than under the benchmark scenario. The energy consumption structures (see Table 11) are obviously optimized, and the changes are consistent with those in scenario I. Compared with the benchmark scenario, the energy consumption intensity decreases nearly $10 \%-11 \%$. Due to the growth of GDP, the energy consumption intensity drops more dramatically than in scenario I. The carbon emissions intensity also decreases significantly, compared with under the benchmark scenario. Generally speaking, reducing the enterprise income tax, when levying the carbon tax, will not only facilitate energy-saving and emission-reduction, but also bring certain growth of the GDP.

Table 11. The total primary energy consumption and its composition (scenario II).

\begin{tabular}{cccccc}
\hline \multirow{2}{*}{ Year } & Total energy consumption & \multicolumn{2}{c}{ The proportion in total primary energies' consumption } \\
\cline { 2 - 6 } & $\mathbf{1 0}$ 10 tons standard coal & Coal & Petroleum & Natural gas & $\begin{array}{c}\text { Hydro power, nuclear } \\
\text { power, and wind power }\end{array}$ \\
\hline 2016 & $430,573.33$ & $61.23 \%$ & $22.91 \%$ & $4.90 \%$ & $10.97 \%$ \\
\hline 2017 & $454,412.63$ & $60.64 \%$ & $23.06 \%$ & $5.03 \%$ & $11.26 \%$ \\
\hline 2018 & $478,559.94$ & $60.07 \%$ & $23.21 \%$ & $5.18 \%$ & $11.54 \%$ \\
\hline 2019 & $502,975.72$ & $59.51 \%$ & $23.34 \%$ & $5.33 \%$ & $11.82 \%$ \\
\hline 2020 & $527,602.03$ & $58.98 \%$ & $23.46 \%$ & $5.48 \%$ & $12.08 \%$ \\
\hline 2021 & $550,428.38$ & $58.38 \%$ & $23.60 \%$ & $5.65 \%$ & $12.37 \%$ \\
\hline 2022 & $573,046.91$ & $57.82 \%$ & $23.72 \%$ & $5.82 \%$ & $12.64 \%$ \\
\hline 2023 & $595,459.85$ & $57.26 \%$ & $23.84 \%$ & $6.00 \%$ & $12.90 \%$ \\
\hline 2024 & $617,670.27$ & $56.73 \%$ & $23.94 \%$ & $6.18 \%$ & $13.15 \%$ \\
\hline 2025 & $639,712.61$ & $56.19 \%$ & $24.03 \%$ & $6.37 \%$ & $13.41 \%$ \\
\hline 2026 & $661,586.46$ & $55.65 \%$ & $24.12 \%$ & $6.56 \%$ & $13.68 \%$ \\
\hline 2027 & $683,339.10$ & $55.12 \%$ & $24.20 \%$ & $6.76 \%$ & $13.92 \%$ \\
\hline 2028 & $704,981.02$ & $54.61 \%$ & $24.27 \%$ & $6.96 \%$ & $14.16 \%$ \\
\hline 2029 & $726,545.53$ & $54.11 \%$ & $24.33 \%$ & $7.17 \%$ & $14.39 \%$ \\
\hline 2030 & $748,071.28$ & $53.61 \%$ & $24.38 \%$ & $7.39 \%$ & $14.62 \%$ \\
\hline
\end{tabular}


Table 12. The analysis of GDP, energy consumption and carbon emission intensity (Scenario III).

\begin{tabular}{|c|c|c|c|c|c|c|c|c|}
\hline \multirow{2}{*}{ Year } & GDP & \multirow{2}{*}{$\begin{array}{l}\text { Percentage } \\
\text { change of } \\
\text { GDP }\end{array}$} & \multirow{2}{*}{$\begin{array}{r}\begin{array}{r}\text { Total energy } \\
\text { consumption }\end{array} \\
\begin{array}{c}10^{4} \text { tons } \\
\text { standard coal }\end{array}\end{array}$} & \multirow{2}{*}{$\begin{array}{l}\text { Percentage change } \\
\text { of total energy } \\
\text { consumption }\end{array}$} & \multirow{2}{*}{$\begin{array}{c}\text { Energy consumption } \\
\text { intensity } \\
\text { ton standard } \\
\text { coal } / 1 \mathbf{1 0}^{4} \text { Yuan }\end{array}$} & \multirow{2}{*}{$\begin{array}{l}\text { Percentage change of } \\
\text { energy consumption } \\
\text { intensity }\end{array}$} & \multirow{2}{*}{$\begin{array}{c}\text { Carbon emissions } \\
\text { intensity }\end{array}$} & \multirow{2}{*}{$\begin{array}{c}\text { Percentage change } \\
\text { of carbon emissions } \\
\text { intensity }\end{array}$} \\
\hline & $10^{9}$ Yuan & & & & & & & \\
\hline 2017 & $602,166.88$ & $-0.06 \%$ & $453,356.92$ & $-8.22 \%$ & 0.7529 & $-8.16 \%$ & 1.7495 & $-8.97 \%$ \\
\hline 2018 & $646,732.90$ & $-0.03 \%$ & $478,281.46$ & $-7.98 \%$ & 0.7395 & $-7.95 \%$ & 1.7182 & $-8.84 \%$ \\
\hline 2019 & $693,360.41$ & $-0.01 \%$ & $503,645.91$ & $-7.72 \%$ & 0.7264 & $-7.71 \%$ & 1.6871 & $-8.71 \%$ \\
\hline 2021 & $791,003.22$ & $0.04 \%$ & $553,621.21$ & $-7.18 \%$ & 0.6999 & $-7.21 \%$ & 1.6234 & $-8.45 \%$ \\
\hline 2022 & $841,580.26$ & $0.06 \%$ & $577,830.18$ & $-6.88 \%$ & 0.6866 & $-6.94 \%$ & 1.5908 & $-8.32 \%$ \\
\hline 2023 & $893,815.02$ & $0.09 \%$ & $602,068.79$ & $-6.57 \%$ & 0.6736 & $-6.65 \%$ & 1.5587 & $-8.20 \%$ \\
\hline 2024 & $947,736.48$ & $0.11 \%$ & $626,355.50$ & $-6.25 \%$ & 0.6609 & $-6.35 \%$ & 1.5272 & $-8.08 \%$ \\
\hline 2025 & $1,003,383.66$ & $0.13 \%$ & $650,716.71$ & $-5.91 \%$ & 0.6485 & $-6.04 \%$ & 1.4962 & $-7.96 \%$ \\
\hline 2026 & $1,060,225.75$ & $0.15 \%$ & $675,141.16$ & $-5.56 \%$ & 0.6368 & $-5.70 \%$ & 1.4672 & $-7.81 \%$ \\
\hline 2030 & $1,305,859.57$ & $0.23 \%$ & $774,558.14$ & $-4.00 \%$ & 0.5931 & $-4.22 \%$ & 1.3573 & $-7.22 \%$ \\
\hline
\end{tabular}


Carbon tax scenario III: When the carbon tax is levied and energy technology of clean power is improved, GDP grows slightly compared with that under the benchmark scenario, and the growth rate rises gradually (see Table 12). We explain this as, although the costs of fossil energy fuels will rise, and enterprises' energy inputs and outputs will fall due to carbon tax, the technology of clean power will be improved, and output of clean energy will increase, which is helpful for lowering the energy prices and promoting the use of clean power, therefore, GDP grows slightly compared with that under benchmark scenario, and the growth rate rises gradually. Table 13 analyzes the total primary energy consumption and its composition, the proportion of coal in the primary energy consumption will drop to $52.58 \%$ by 2030 , while the proportion of hydro power, nuclear power, and wind power will rise to $17.77 \%$ and the proportions of petroleum and natural gas are lower than those under the benchmark scenario. At the same time, compared with the benchmark scenario, the total energy consumption reduces slightly but in a decreased reduction rate, so does the trend of energy consumption intensity. In addition, due to the optimization of energy consumption structure, the carbon emissions intensity decreases more than $7 \%-9 \%$ each year compared with the benchmark scenario. Therefore, the improvement of clean power technology is significant to the optimization of energy consumption structure and carbon emission reductions. However, the cost reduction of the fossil energy fuels caused by the improvement of clean power technology partly improves the total energy demand.

Table 13. The total primary energy consumption and its composition (scenario III).

\begin{tabular}{cccccc}
\hline \multirow{2}{*}{ Year } & Total energy consumption & \multicolumn{3}{c}{ The proportion in total primary energies' consumption } \\
\cline { 2 - 6 } & $\mathbf{1 0}$ tons standard coal & Coal & Petroleum & Natural gas & $\begin{array}{c}\text { Hydro power, nuclear } \\
\text { power, and wind power }\end{array}$ \\
\hline 2016 & $428,901.61$ & $62.39 \%$ & $22.29 \%$ & $4.75 \%$ & $10.56 \%$ \\
\hline 2017 & $453,356.92$ & $61.76 \%$ & $22.35 \%$ & $4.87 \%$ & $11.01 \%$ \\
\hline 2018 & $478,281.46$ & $61.12 \%$ & $22.41 \%$ & $5.00 \%$ & $11.47 \%$ \\
\hline 2019 & $503,645.91$ & $60.47 \%$ & $22.46 \%$ & $5.13 \%$ & $11.94 \%$ \\
\hline 2020 & $529,432.47$ & $59.82 \%$ & $22.50 \%$ & $5.27 \%$ & $12.41 \%$ \\
\hline 2021 & $553,621.21$ & $59.11 \%$ & $22.56 \%$ & $5.42 \%$ & $12.91 \%$ \\
\hline 2023 & $577,830.18$ & $58.39 \%$ & $22.61 \%$ & $5.58 \%$ & $13.43 \%$ \\
\hline 2024 & $602,068.79$ & $57.67 \%$ & $22.65 \%$ & $5.74 \%$ & $13.94 \%$ \\
\hline 2025 & $626,355.50$ & $56.94 \%$ & $22.68 \%$ & $5.90 \%$ & $14.47 \%$ \\
\hline 2026 & $650,716.71$ & $56.22 \%$ & $22.71 \%$ & $6.07 \%$ & $15.00 \%$ \\
\hline 2027 & $675,141.16$ & $55.49 \%$ & $22.72 \%$ & $6.24 \%$ & $15.54 \%$ \\
\hline 2028 & $699,691.21$ & $54.77 \%$ & $22.72 \%$ & $6.42 \%$ & $16.09 \%$ \\
\hline 2029 & $724,410.48$ & $54.04 \%$ & $22.71 \%$ & $6.60 \%$ & $16.64 \%$ \\
\hline 2030 & $749,348.09$ & $53.31 \%$ & $22.70 \%$ & $6.79 \%$ & $17.20 \%$ \\
\hline
\end{tabular}

\section{Conclusions and Policy Suggestions}

Overall, under the benchmark scenario, China will continue a relatively high growth rate in the economy, but the growth rate will slow down. Although the energy consumption intensity per unit of GDP and carbon emissions intensity per unit of GDP continually decrease, energy consumption structure and the industrial structure will be gradually optimized, total energy consumption will rise with 
economic growth, the carbon dioxide emissions will still be large, and the situation of energy-saving and emission-reduction will be grim. The carbon tax is vital for energy-saving, emission-reduction, and energy consumption structure optimization. Meanwhile, the effect of carbon tax on GDP is not great. If enterprise income tax can be reduced, while levying carbon tax, not only can we reduce energy consumption and carbon emissions, but also increase the GDP to a certain degree. Furthermore, the improvement of clean power technology is very important for optimizing energy consumption structure and reducing carbon emission when the carbon tax is implemented, but this will partly offset the reduction of energy consumption. Therefore, we make the following suggestions for future economic development in China.

(1) It is suggested to strengthen the optimization and adjustment of industrial structure. We should suppress excessive growth of the high energy demand and high emission industries, and promote the optimization and upgrading of traditional industries by means of new technologies and advanced applicable technologies. In the meantime, development of service industries and strategic new industries should be promoted productive service industries and life service industries should be accelerated.

(2) We propose to optimize the production and consumption structure of energies. We should improve the efficiency of coal processing and conversion, and the utilization level of clean energy. It is necessary to establish large-scale coal and electricity bases, and develop thermal power efficiently and cleanly. Actively develop a new coal chemical industry, relying on technological progress. Great importance should be attached to the development of renewable energy with the utilization of wind energy, solar energy, and biomass energy as the focus, and hydropower should also be developed actively and orderly. At the same time, we should actively explore and develop the coal-bed methane and shale gas.

(3) It is urgent to implement the carbon tax policy and other effective policies for energy-saving and emission-reduction. An effective carbon tax policy for reducing carbon emissions needs to be carried out, and the mode of levying a carbon tax, and how to recycle the carbon tax, needs to be studied. In order to reduce energy consumption and carbon emissions, it is also required to improve laws and regulations, economic policies, and administrative measures.

\section{Acknowledgments}

The authors gratefully acknowledge the financial support from the National Science Foundation of China (Grant NO. 71173075), Program for New Century Excellent Talents in University (NCET-12-0850) and China Postdoctoral Science Foundation (Grant NO. 2012M520222). We would also like to thank the editors and anonymous reviewers.

\section{Author Contributions}

Zhengquan Guo and Yuhua Zheng established the CGE model and made the analysis results together. Yuanying Chi completed the papers in English. Xingping Zhang gave many good research advices. 


\section{Conflicts of Interest}

The authors declare no conflict of interest.

\section{References}

1. Akkemik, K.A.; Oguz, F. Regulation, efficiency and equilibrium: A general equilibrium analysis of liberalization in the Turkish electricity market. Energy 2011, 36, 3282-3292.

2. Xie, J.; Saltzman, S. Environmental policy analysis: An environmental computable general-equilibrium approach for developing countries. J. Policy Model. 2000, 22, 453-489.

3. Fraser, I.; Waschik, R. The double dividend hypothesis in a CGE model: Specific factors and the carbon base. Energy Econ. 2013, 39, 283-295.

4. Caron, J. Estimating carbon leakage and the efficiency of border adjustments in general equilibrium-Does sectoral aggregation matter? Energy Econ. 2012, 34, S111-S126.

5. Boccanfuso, D.; Savard, L.; Estache, A. The distributional impact of developed countries' climate change policies on senegal: A macro-micro CGE application. Sustainability 2013, 5, 2727-2750.

6. Vennemo, H. A dynamic applied general equilibrium model with environmental feedbacks. Econ. Model. 1997, 14, 99-154.

7. Wendner, R. An applied dynamic general equilibrium model of environmental tax reforms and pension policy. J. Policy Model. 2001, 21, 25-50.

8. Muto, S.; Morisugi, H.; Ueda, T. Measuring Market Damage of Automobile Related Carbon Tax by Dynamic Computable General Equilibrium Model. In Proceedings of the 2003 ERSA Conference, Jyväskylä, Finland, 27-30 August 2003; European Regional Science Association: Louvain-la-Neuve, Belgium, 2003; No.ersa03p257.

9. Fukiharu, T. The global warming, sustainability and environmental tax: A dynamic general equilibrium model. Environ. Softw. Syst. Framew. Environ. 2011, 359, 566-573.

10. Matsumoto, K. Economic analysis of $\mathrm{CO}_{2}$ emission abatement applying a dynamic CGE model with endogenous technological change: Impacts of the time horizon. J. Environ. Sci. Eng. 2011, 5, 1454-1463.

11. O’Ryan, R.; de Miguel, C.J.; Miller, S.; Pereira, M. The socioeconomic and environmental effects of free trade agreements: A dynamic CGE analysis for Chile. Environ. Dev. Econ. 2011, 16, $305-327$.

12. Hermeling, C.; Loschel, A.; Mennel, T. A new robustness analysis for climate policy evaluations: A CGE application for the EU 2020 targets. Energy Policy 2013, 55, 27-35.

13. He, Y.X.; Zhang, S.L.; Yang, L.Y.; Wang, Y.J.; Wang, J. Economic analysis of coal price-electricity price adjustment in China based on the CGE model. Energy Policy 2010, 38, 6629-6637.

14. Lin, B.Q.; Jiang, Z.J. Estimates of energy subsidies in China and impact of energy subsidy reform. Energy Econ. 2011, 33, 273-283.

15. Ren, S.; Yuan, Y.; Wang, H.; Ji, F. Research on the influence of sulfur tax on the industrial structure of liaoning province under CGE model. Energy Procedia 2011, 5, 2405-2409. 
16. He, Y.X.; Yang, L.F.; He, H.Y.; Luo, T.; Wang, Y.J. Electricity demand price elasticity in China based on computable general equilibrium model analysis. Energy 2011, 36, 1115-1123.

17. Lu, C.Y.; Zhang, X.L.; He, J.K. A CGE analysis to study the impacts of energy investment on economic growth and carbon dioxide emission: A case of Shanxi Province in western China. Energy 2010, 35, 4319-4327.

18. Zhang, Z.K.; Guo, J.E.; Qian, D.; Xue, Y.; Cai, L.P. Effects and mechanism of influence of China's resource tax reform: A regional perspective. Energy Econ. 2013, 36, 676-685.

19. Zhang, Z.X. Macroeconomic Effects of $\mathrm{CO}_{2}$ Emission Limits: A Computable General Equilibrium Analysis for China; 1996 Mansholt Working Papers; Wageningen University: Wageningen, The Netherlands, 1996; No. 01-96.

20. Zhang, Z.X. Macroeconomic effects of $\mathrm{CO}_{2}$ emission limits: A computable general equilibrium analysis for China. J. Policy Model. 1998, 20, 213-250.

21. Garbaccio, R.F.; Ho, M.S.; Jorgenson, D.W. Controlling carbon emissions in China. Environ. Dev. Econ. 1999, 4, 493-518.

22. Liang, Q.M.; Fan, Y.; Wei, Y.M. Carbon taxation policy in China: How to protect energy- and trade-intensive sectors? J. Policy Model. 2007, 29, 311-333.

23. Lu, C.Y.; Tong, Q.; Liu, X.M. The impacts of carbon tax and complementary policies on Chinese economy. Energy Policy 2010, 38, 7278-7285.

24. Tang, L.; Bao, Q.; Zhang, Z.X.; Wang, S.Y. Carbon-based Border Tax Adjustments and China's International Trade: Analysis Based on a Dynamic Computable General Equilibrium Model; 2013 Working Papers; Fondazione Eni Enrico Mattei: Milan, Italy, 2013; Volume 17.

25. Burniaux, J.-M.; Martin, J.P.; Nicoletti, G.; Martins, J.O. GREEN a Multi-Sector, Multi-Region General Equilibrium Model for Quantifying the Costs of Curbing $\mathrm{CO}_{2}$ Emissions: A Technical Manual; 1992 OECD Economics Department Working Papers; IDEAS: Paris, France, 1992; No. 116.

26. Huang, Y.N.; Zhang, W.; Wang, X.J. An econometric estimation and selection on the production function in an environmental CGE model. ACTA Sci. Circumst. 2003, 23, 350-354.

27. Wu, Y.J.; Xuan, X.W. The Economic Theory of Environmental Tax and Its Application in China; Economic Science Press: Beijing, China, 2002.

28. Intergovernmental Panel on Climate Change. The 2006 IPCC Guidelines for National Greenhouse Gas Inventories. Available online: http://www.ipcc-nggip.iges.or.jp/public/2006gl/index.html (accessed on 19 November 2013).

29. National Bureau of Statistics PR China. China Statistical Yearbook 2010; China Statistics Press: Beijing, China, 2010.

30. National Bureau of Statistics PR China. China Statistical Yearbook 1999; China Statistics Press: Beijing, China, 1999.

31. National Bureau of Statistics PR China. China Energy Statistical Yearbook 2008; China Statistics Press: Beijing, China, 2008.

32. He, J.H.; Shen, K.T.; Xu, S.L. CGE model of the carbon tax and carbon dioxide emission reduction. Quant. Tech. Econ. 2002, 10, 39-47.

33. Wang, C. Climate Change Policy Simulation and Uncertainty Analysis: A Dynamic CGE Model of China. Ph.D. Thesis, Tsinghua University, Beijing, China, 2003. 
34. Xuan, X.W. Analysis the Effect of Sulfur-Tax on the CHINESE Economy Based on CGE Model. Ph.D. Thesis, Peking University, Beijing, China, 1998.

35. Tan, X.D. Modeling and Application of Electric Power Computable General Equilibrium Model. Ph.D. Thesis, North China Electric Power University, Beijing, China, 2008.

36. Wang, D.W. Changes in the relationship between labor supply and labor demand and China's economic growth in the low fertility era. Chin. J. Popul. Sci. 2007, 1, 44-52.

37. Wang, J.Y.; Lin, L.L. Analysis on labor force participation rate and future labor supply in China. Popul. J. 2006, 4, 19-24.

38. Wang, G.X. Study on the transfer of rural surplus labor in China-the quantity estimate of rural surplus labor and the forecast of its transfer scale. J. Shanxi Univ. 2007, 30, 19-24.

(C) 2014 by the authors; licensee MDPI, Basel, Switzerland. This article is an open access article distributed under the terms and conditions of the Creative Commons Attribution license (http://creativecommons.org/licenses/by/3.0/). 